\title{
Effect of nagilactone E on cell morphology and glucan biosynthesis in budding yeast Saccharomyces cerevisiae
}

Kengo Hayashi, Yoshihiro Yamaguchi, Akira Ogita, Toshio Tanaka, Isao Kubo, Ken-ichi Fujita

\begin{tabular}{|c|l|}
\hline Citation & Fitoterapia, 128; 112-117 \\
\hline Issue Date & $2018-07$ \\
\hline Type & Journal article \\
\hline Textversion & Author \\
\hline & $\begin{array}{l}\text { O2018 Elsevier B.V. This manuscript version is made available under the CC-BY-NC-ND } \\
\text { Rights }\end{array}$ \\
$\begin{array}{l}\text { This is the accept manuscript version. The article has been published in final form at } \\
\text { https://doi.org/10.1016/j.fitote.2018.05.003 }\end{array}$ \\
\hline DOI & \begin{tabular}{l} 
10.1016/j.fitote.2018.05.003 \\
\hline
\end{tabular} \\
\hline
\end{tabular}

Self-Archiving by Author(s)

Placed on: Osaka City University

HAYASHI, K., YAMAGUCHI, Y., OGITA, A., TANAKA, T., KUBO, I., \& FUJITA, K.-I. (2018). Effect of nagilactone E on cell morphology and glucan biosynthesis in budding yeast Saccharomyces cerevisiae. Fitoterapia. 128, 112-117. 
Effect of nagilactone $\mathbf{E}$ on cell morphology and glucan biosynthesis in budding yeast Saccharomyces cerevisiae

Kengo Hayashi ${ }^{\text {a }}$, Yoshihiro Yamaguchi ${ }^{\text {a,b }}$, Akira Ogita ${ }^{\text {acc }}$, Toshio Tanaka a ${ }^{\text {, Isao Kubo }}{ }^{\text {d, }}$ Ken-ichi Fujita ${ }^{a, *}$

a Graduate School of Science, Osaka City University, Sumiyoshi-ku, Osaka, Japan

b Advanced Research Institute for Natural Science and Technology, Osaka City University, Sumiyoshi-ku, Osaka, Japan

c Research Center for Urban Health and Sports, Osaka City University, Sumiyoshi-ku, Osaka, Japan

d Department of Environmental Science, Policy and Management, University of California, Berkeley, CA, United States

* Corresponding author at: Graduate School of Science, Osaka City University, 3-3-138 Sugimoto, Sumiyoshi-ku, Osaka 558-8585, Japan

TEL \& FAX: +81-6-6605-2580

E-mail address: kfujita@sci.osaka-cu.ac.jp (K. Fujita) 


\section{ABSTRACT}

Nagilactones are norditerpene dilactones isolated from the root bark of Podocarpus nagi. Although nagilactone $\mathrm{E}$ has been reported to show antifungal activities, its activity is weaker than that of antifungals on the market. Nagilactone E enhances the antifungal activity of phenylpropanoids such as anethole and isosafrole against nonpathogenic Saccharomyces cerevisiae and pathogenic Candida albicans. However, the detailed mechanisms underlying the antifungal activity of nagilactone $\mathrm{E}$ itself have not yet been elucidated. Therefore, we investigated the antifungal mechanisms of nagilactone $\mathrm{E}$ using S. cerevisiae. Although nagilactone E induced lethality in vegetatively growing cells, it did not affect cell viability in non-growing cells. Nagilactone E-induced morphological changes in the cells, such as inhomogeneous thickness of the glucan layer and leakage of cytoplasm. Furthermore, a dose-dependent decrease in the amount of newly synthesized $(1,3)$ - $\beta$-glucan was detected in the membrane fractions of the yeast incubated with nagilactone E. These results suggest that nagilactone E exhibits an antifungal activity against $S$. cerevisiae by depending on cell wall fragility via the inhibition of $(1,3)-\beta$ glucan biosynthesis. Additionally, we confirmed nagilactone E-induced morphological changes of a human pathogenic fungus Aspergillus fumigatus. Therefore, nagilactone E is a potential antifungal drug candidate with fewer adverse effects.

Key words: antifungal, Aspergillus fumigatus, (1, 3)- $\beta$-glucan, nagilactone E, Saccharomyces cerevisiae

Abbreviations: amphotericin B (AmB), polyethylene glycol tert-octylphenyl ether (Triton $\mathrm{X}-100)$, micafungin (MCFG), minimum growth inhibitory concentration (MIC), malt extract (ME), colony forming unit (CFU). 


\section{Introduction}

Novel antifungal drugs with new modes of action are urgently required owing to an increase in opportunistic fungal infections in immunocompromised patients and the elderly [1]. Current targets of antifungals are limited to the functions and structures unique to fungi; for example, ergosterol, the cell wall and cytosine deaminase. Polyene macrolide antifungals typified by amphotericin $\mathrm{B}(\mathrm{AmB})$ directly bind ergosterol in the plasma membrane to form pores in the membrane [2]. These drugs have excellent antifungal potencies but can cause nephropathy. Azole antifungals such as miconazole, fluconazole, and itraconazole inhibit ergosterol biosynthesis [3]. However, clinical isolates have been reported to show resistance to azoles [4]. The most recently developed echinocandins, including micafungin, anidulafungin, and caspofungin, inhibit $(1,3)-\beta$-glucan synthase, thereby weakening the fungal cell wall [5]. As the structure and biosynthesis of fungal cell wall are unique to fungi, it is an excellent target for the development of antifungal drugs $[6,7]$.

Nagilactones are norditerpene dilactones isolated from the root bark of Podocarpus nagi, an evergreen tree belonging to Podocarpaceae that grows mainly in western Japan. They exhibit biological activities such as plant growth inhibitory and antiherbivory effects $[8,9]$. Among them, nagilactones $\mathrm{C}, \mathrm{D}$, and $\mathrm{F}$ show insect-feeding-deterrent activities 
[10]. Nagilactone $\mathrm{C}$ also showed insecticidal [11] and potent antitumor activities [12]. In contrast, nagilactone E (Fig. 1) has been reported to show antifungal activities against a nonpathogenic budding yeast Saccharomyces cerevisiae and two human opportunistic fungal pathogens, Candida albicans and Pityrosporum ovale [13] in addition to potent cytotoxic activities against P388 murine leukemia cells [14]. The antifungal activity of nagilactone $\mathrm{E}$ is weaker than that of antifungal drugs on the market, but nagilactone $\mathrm{E}$ enhances the antifungal activity of phenylpropanoids such as anethole and isosafrole against $S$. cerevisiae and C. albicans $[13,15]$. Thus, nagilactone E combined with other drugs has potential for clinical application with less severe adverse effects.

The antifungal mechanisms of nagilactone $\mathrm{E}$ itself have not yet been reported. Concerning synergistic effects in combination of drugs, the action mode of one drug is prominently enhanced by another drug, which restricts drug resistance $[16,17]$. In the case of nagilactone E, such a phenomenon possibly occurs. Therefore, to gain insight into the pharmacological application of nagilactone E with less severe adverse effects in combination with other drugs, analyzing the action mechanisms of nagilactone $\mathrm{E}$ alone is expected to provide beneficial cues. Herein, we investigated the antifungal mechanism of nagilactone E against $S$. cerevisiae, which is a model fungus, based on cell viability, changes in cell morphology, visualization of $(1,3)-\beta$-glucan, and $(1,3)-\beta$-glucan synthase 
activity. In addition, we examined the effect of nagilactone $\mathrm{E}$ on a human pathogenic fungus Aspergillus fumigatus and its morphology.

\section{Materials and methods}

\subsection{Chemicals}

Nagilactone E was from laboratory stock [13]. AmB was purchased from Sigma-Aldrich (St. Louis, MO, USA). Polyethylene glycol tert-octylphenyl ether (Triton X-100) was obtained from Alfa Aesar (Lancashire, UK). Micafungin (MCFG) was a gift from Astellas Pharma Inc. (Tokyo, Japan). The drugs were dissolved in dimethyl sulfoxide (DMSO) prior to the following experiments. All other chemicals used were of analytical grade.

\subsection{Measurement of cell growth and viability}

The parent strain of $S$. cerevisiae BY4741 was obtained from the Yeast Knock Out Strain Collection (Thermo Scientific Open Biosystems, Waltham, MA, USA). The yeast cells were grown overnight at $30^{\circ} \mathrm{C}$ with vigorous shaking in YPD medium consisting 
of 1\% Bacto-yeast extract (Difco Laboratories, Detroit, MI, USA), 2\% Bacto-peptone (Difco Laboratories), and 2\% D-glucose prior to experiments unless stated otherwise.

A wild-type strain Aspergillus fumigatus NBRC 5840 was obtained from the Biological Resource Center, NITE (Tokyo, Japan). The fungus was maintained on 2.5\% malt extract (ME; Oriental Yeast Co., Ltd, Tokyo, Japan) agar plates.

The in vitro minimum growth inhibitory concentration (MIC) of nagilactone $\mathrm{E}$ against S. cerevisiae was determined by the two-fold broth dilution method described previously [18]. Cells were harvested, washed with $2.5 \%$ malt extract (ME; Oriental Yeast Co., Ltd, Tokyo, Japan) medium, diluted to $1 \times 10^{6}$ cells $/ \mathrm{mL}$ in the same medium, and then incubated with various concentrations of nagilactone $\mathrm{E}$ at $30^{\circ} \mathrm{C}$ for $24 \mathrm{~h}$ in a 96-well plate (the final volume of cell suspension at $100 \mu \mathrm{L}$ ). The MIC of nagilactone $\mathrm{E}$ was determined as the lowest concentration in which no visible growth was observed. All assays were repeated at least three times.

The in vitro MIC of nagilactone $\mathrm{E}$ against $A$. fumigatus was determined as described above except that the fungus was directly suspended at $1 \times 10^{6}$ germinated spores $/ \mathrm{mL}$ in ME medium prior to the MIC assay.

For time-kill assay, the yeast cells were diluted to $1 \times 10^{7}$ cells $/ \mathrm{mL}$ in ME medium containing 0,100 , or $200 \mu \mathrm{g} / \mathrm{mL}$ nagilactone E. Cell suspensions were incubated with 
vigorous shaking at $30^{\circ} \mathrm{C}$. Aliquots were withdrawn from the suspensions and then spread on YPD plates. The cell viability was determined as the number of colony forming units (CFUs). Data are means \pm standard deviations of triplicate experiments.

\subsection{Leakage of potassium ions and $260 \mathrm{~nm}$-absorbing materials}

The $S$. cerevisiae cells cultured overnight in YPD medium were harvested by centrifugation and washed with $50 \mathrm{mM}$ sodium succinate buffer (S-buffer, $\mathrm{pH}$ 6.0). The yeast cells were then suspended at a cell density of $1 \times 10^{8}$ cells $/ \mathrm{mL}$ in S-buffer containing 0, 100, or $200 \mu \mathrm{g} / \mathrm{mL}$ nagilactone E. Cell suspensions were incubated with vigorous shaking at $30{ }^{\circ} \mathrm{C}$. The supernatants obtained after removal of the cells by centrifugation were used to quantify $\mathrm{K}^{+}$ions released from the cells. The quantification was performed with a $\mathrm{K}^{+}$ion assay kit based on the tetraphenylborate method $[19,20]$. The supernatants were also used to measure leakage of 260-nm-absorbing materials as an index of nonspecific plasma membrane disruption, which represents the leakage of intracellular nucleosides, nucleotides, and other related compounds with absorption optima at around $260 \mathrm{~nm}[20,21]$. AmB and Triton X-100 were used as positive controls of agents causing leakage of intracellular potassium ions and $260 \mathrm{~nm}$-absorbing materials, respectively. Finally, the cell viability in S-buffer was also determined as CFUs after a 72-h incubation. 
Data are means \pm standard deviations of triplicate experiments.

\subsection{Cell wall chitin staining with calcofluor white}

Cell wall chitin staining with calcofluor white was performed according to the methods of Yutani et al. [22] with slight modifications. The cells of $S$. cerevisiae BY4741 $\left(10^{7}\right.$ cells $/ \mathrm{mL}$ ) were incubated with 0 and $200 \mu \mathrm{g} / \mathrm{mL}$ nagilactone $\mathrm{E}$ at $30^{\circ} \mathrm{C}$ with vigorous shaking for $72 \mathrm{~h}$. The cells were washed with deionized water and then incubated in deionized water at $25{ }^{\circ} \mathrm{C}$ for $1 \mathrm{~h}$. Calcofluor white (Sigma-Aldrich) at $1 \mathrm{mg} / \mathrm{mL}$ was added to the cell suspension. After incubation at $25^{\circ} \mathrm{C}$ for $5 \mathrm{~min}$ in the dark, chitin was visualized using a fluorescence microscope (excitation wavelength, $330 \mathrm{~nm}$; emission wavelength, $385 \mathrm{~nm})$.

\subsection{Cell wall glucan staining with aniline blue dye}

The cells of $S$. cerevisiae BY4741 $\left(10^{7}\right.$ cells $\left./ \mathrm{mL}\right)$ were incubated with vigorous shaking in ME medium containing 0 and $200 \mu \mathrm{g} / \mathrm{ml}$ nagilactone $\mathrm{E}$ at $30^{\circ} \mathrm{C}$ for $72 \mathrm{~h}$. The cells were washed with deionized water and then incubated in deionized water at $25^{\circ} \mathrm{C}$ for 1 h. Aniline blue dye (Wako Pure Chemicals Industries, Osaka, Japan) at $5 \mathrm{mg} / \mathrm{mL}$ was added to the cell suspension. After incubation at room temperature for $5 \mathrm{~min}$ in the dark, 
$(1,3)$ - $\beta$-glucan of cell wall was visualized using a fluorescence microscope (excitation wavelength, $330 \mathrm{~nm}$; emission wavelength, $385 \mathrm{~nm}$ ).

\subsection{Antifungal assay under hyperosmotic conditions}

An antifungal assay under hyperosmotic conditions using sorbitol was performed according to the methods of Frost et al. [23] with slight modifications. Briefly, cells were suspended to $5 \times 10^{5}$ cells $/ \mathrm{mL}$ in yeast nitrogen base (Difco Laboratories) containing $0.67 \%$ glucose, $3 \mathrm{mM}$ leucine, $12 \mathrm{mM}$ adenine, and $0.67 \mathrm{mM}$ uracil. Sorbitol at $0.8 \mathrm{M}$ was further added to the medium as an osmotic support. The culture was then incubated in the presence of various concentrations of nagilactone $\mathrm{E}$ at $30^{\circ} \mathrm{C}$ for 2 and 7 days in a 48-well plate (the final volume at $500 \mu \mathrm{l}$ ) prior to MIC determination in treatment with or without $0.8 \mathrm{M}$ sorbitol. All assays were repeated at least three times.

\subsection{Preparation of membrane fractions and assay for $(1,3)-\beta$-glucan synthase}

An assay for $(1,3)$ - $\beta$-glucan synthase in $S$. cerevisiae cells was performed according to the methods of Shedletzky et al. [24] and Mizuhara et al. [25] with slight modifications. Briefly, S. cerevisiae BY4741 cells were grown at $30^{\circ} \mathrm{C}$ in YPD medium until mid-log phase. Exponentially growing cells were harvested and washed with a breakage buffer 
(50 mM Tris/HCl (pH 7.5) with $1 \mathrm{mM}$ EGTA). Dithiothreitol at $4 \mathrm{mM}$ (Wako Pure Chemicals Industries) and 1.0\% (v/v) of a protease inhibitor cocktail for fungi (SigmaAldrich) were added to the suspension. The cells were broken by 12 cycles of $10 \mathrm{sec}$ with 0.5-mm acid-washed glass beads using a bead beater (Bio Medical Science, Tokyo, Japan). The crude homogenate was centrifuged at $3,000 \times g$ at $4{ }^{\circ} \mathrm{C}$ for $10 \mathrm{~min}$, and the supernatant containing microsomes and membranes was gathered by centrifugation at $100,000 \times g$ at $4{ }^{\circ} \mathrm{C}$ for $1 \mathrm{~h}$. The pellet was resuspended in $1 \mathrm{~mL}$ of the breakage buffer, which contained $33 \%(\mathrm{v} / \mathrm{v})$ glycerol and $0.25 \%(\mathrm{v} / \mathrm{v})$ of the protease inhibitor cocktail, and then stored at $-80^{\circ} \mathrm{C}$ as enzyme solutions until assay. Protein concentration was determined using the Bradford reagent (Sigma-Aldrich), and the protein content of the membrane fraction was approximately $1.12 \mathrm{mg} / \mathrm{mL}$.

For (1, 3)- $\beta$-glucan synthase assay, $90 \mu \mathrm{L}$ of enzyme solutions was mixed with 78 $\mu \mathrm{L}$ of Tris/ $\mathrm{HCl}$ solution (50 mM Tris/HCl (pH 7.5), $8 \mathrm{mM}$ EDTA-2Na, 4.3\% (v/v) Tween $20,16.5 \%(\mathrm{v} / \mathrm{v})$ glycerol), $10 \mu \mathrm{L}$ of breakage buffer, $2 \mu \mathrm{L}$ of $0.25 \mathrm{M} \mathrm{GTP}$, and $20 \mu \mathrm{L}$ of $0.2 \mathrm{M}$ UDP-glucose. After the addition of $2 \mu \mathrm{L}$ drug solutions $(0,100$, and $200 \mu \mathrm{g} / \mathrm{mL}$ nagilactone $\mathrm{E}, 10 \mu \mathrm{M}$ MCFG as a positive control) to each sample, all the reaction mixtures were incubated for $30 \mathrm{~min}$ at $30^{\circ} \mathrm{C}$ and stopped by adding $40 \mu \mathrm{L}$ of $6 \mathrm{M} \mathrm{NaOH}$. Newly formed glucans were solubilized by incubating the reaction samples at $80{ }^{\circ} \mathrm{C}$ for 
$30 \mathrm{~min}$. Next, the samples were added to $840 \mu \mathrm{L}$ of aniline blue solution (40:21:119 of $0.2 \%$ aniline blue, $1 \mathrm{M} \mathrm{HCl}$, and glycine/ $\mathrm{NaOH}$ buffer (7:3 of $1 \mathrm{M}$ glycine: $1 \mathrm{M} \mathrm{NaOH})$ ). The reaction mixtures were further incubated at $50{ }^{\circ} \mathrm{C}$ for $30 \mathrm{~min}$ and at $25^{\circ} \mathrm{C}$ in the dark for $30 \mathrm{~min}$. Fluorescence derived from the glucan-aniline blue complex was quantified (excitation wavelength, $400 \mathrm{~nm}$; emission wavelength, $460 \mathrm{~nm}$ ) using the F-7000 fluorescence spectrophotometer (Hitachi, Tokyo, Japan). The data are means \pm standard deviations of triplicate experiments.

\subsection{Statistical methods}

Statistical evaluation was performed using Student's $t$-test; $\mathrm{P}<0.05$ indicated significance.

\section{Results}

\subsection{Effects of nagilactone $E$ on cell viability}

MIC of nagilactone E was $25 \mu \mathrm{g} / \mathrm{mL}$ against $S$. cerevisiae. Moreover, cell viability was estimated based on CFU in cells treated with or without nagilactone E. As shown in Fig. 2, cell viability significantly and gradually reduced over the time course of drug exposure, indicating the weak fungicidal effect of nagilactone E. Fungicidal action possibly depends 
on disruption of the plasma membrane and/or cell wall, which are involved in maintenance of the fungal cell architecture, rather than metabolism such as protein synthesis, which is essential for vegetative proliferation [20]. However, when the $S$. cerevisiae cells were treated with $100 \mu \mathrm{g} / \mathrm{mL}$ of nagilactone $\mathrm{E}$, cell viability was slightly restored after 48-h drug exposure. This possibly indicates the mobilization of the drugresistance mechanism.

\subsection{Effect of nagilactone E on plasma membrane permeability}

We measured leakage of intracellular potassium ions and $260 \mathrm{~nm}$-absorbing materials from the yeast cells treated with or without nagilactone $\mathrm{E}$ in comparison with AmB-and Triton X-100-treated cells as positive controls of membrane-disordering agents. AmB induces the $\mathrm{K}^{+}$ion efflux from cells by forming the corresponding ion channel across the plasma membrane (Figure 3a) [26, 27]. Triton X-100 induces rapid solubilization of phospholipids, resulting in a highly disordered spatial arrangement of phospholipids owing to the intramembrane assembly of the surfactant [20]. $\mathrm{K}^{+}$ion efflux was not observed in the cells treated with nagilactone E even at $200 \mu \mathrm{g} / \mathrm{ml}$ after drug exposure for at least $4 \mathrm{~h}$ (Fig. 3a). In addition, the leakage of $260 \mathrm{~nm}$-absorbing materials was not observed after drug exposure for 4 or $72 \mathrm{~h}$ (Fig. 3b). Although cell viability was reduced 
in ME medium for such drug exposure (Fig. 2), cell viability was maintained at the control level when the cells were incubated in S-buffer, lacking energy sources (Fig. 3c). These results suggest that nagilactone $\mathrm{E}$ did not induce rapid plasma membrane-disruptive damage, unlike AmB and Triton X-100.

\subsection{Effect of hyperosmotic conditions on the antifungal activity of nagilactone E}

The presence of osmotic stabilizers such as sorbitol could restore cell proliferation following impairment of the cell wall by antifungal agents [23]. To analyze whether nagilactone E affects the fungal cell wall, the MIC of nagilactone E against $S$. cerevisiae cells was also determined under hyperosmotic conditions such as $0.8 \mathrm{M}$ sorbitol. As shown in Table 1, the MIC of nagilactone E against $S$. cerevisiae cells in the presence of sorbitol increased by two-fold compared with that in the absence of sorbitol after drug exposure for not 2 but 7 days. This indicated the possibility of nagilactone E-induced fragility of fungal cell wall.

\subsection{Effect of nagilactone E on chitin distribution in cell wall}

Chitin is considered a relatively minor component (only $1-2 \%$ of the yeast cell by dry weight), yet structurally important [28]. In yeasts, chitin is localized at the bud tip during 
polarized growth and the bud neck during cytokinesis [6]. Calcofluor white binds chitin and cellulose and is therefore used to visualize the cell walls of fungi and other microorganisms. As shown in Fig. 4a, calcofluor white-positive regions were not altered in the presence or absence of nagilactone $\mathrm{E}$. These results indicated that nagilactone $\mathrm{E}$ did not affect the localization and biosynthesis of chitin.

\subsection{Effect of nagilactone E on glucan distribution in cell wall}

Glucan is the major structural component of the fungal cell wall, constituting approximately $50-60 \%$ of the wall by dry weight $[6,29]$. Aniline blue dye specifically binds to glucan and is frequently used to visualize glucan of the fungal cell wall [24]. After cultivation with or without nagilactone $\mathrm{E}$ for $72 \mathrm{~h}$, the cells were washed twice with deionized water. The washed cells stained with aniline blue dye were observed under fluorescence microscopy. The envelopes of control cells were stained uniformly, indicating that aniline blue-positive material, namely glucan, was localized only in the thick cell wall (Fig. 4b). The surfaces of nagilactone E-treated cells were not stained uniformly and intensely (Fig. 4b). Aniline blue-concentrated or -positive regions were also observed in the cytoplasm of treated cells, and materials leaked from cytoplasm were recognized under phase contrast microscopy (Fig. 4b, Phase contrast). These results 
probably indicated that aberration in the cell walls and the succeeding physically disruption of cells were caused by fragile cell walls under hypoosmotic conditions.

\subsection{Effect of nagilactone E on (1, 3)- $\beta$-glucan synthase}

The increased MIC value of nagilactone $\mathrm{E}$ was observed under hyperosmotic conditions

(Table 1). In addition, a change in materials stained with aniline blue dye was detected in the cells treated with nagilactone E (Fig. 4b). These results implied that one of the possible targets of nagilactone E was the cell wall in S. cerevisiae cells. Therefore, we examined whether nagilactone E inhibits the (1,3)- $\beta$-glucan synthase of $S$. cerevisiae cells in an in vitro assay using membrane fractions derived from the cells as the enzyme sources and UDP-glucose as a substrate. As shown in Fig. 4c, $10 \mu \mathrm{M}$ MCFG, as a potent inhibitor of $(1,3)$ - $\beta$-glucan synthase [30], expectedly restricted the newly synthesized amounts of (1, $3)-\beta$-glucan by $64 \%$ in the membrane fractions. On the other hand, the amounts of $(1,3)$ $\beta$-glucan decreased by $21 \%$ and $30 \%$ in the membrane fractions treated with 100 and 200 $\mu \mathrm{g} / \mathrm{mL}$ nagilactone $\mathrm{E}$, respectively, as compared with that in cells treated without nagilactone E (Fig. 4c). These results indicate that the fragility of the cell wall could be partly explained by inhibition of the $(1,3)-\beta$-glucan synthase. 


\subsection{Effect of nagilactone E on human pathogenic fungus A. fumigatus}

The fibrillar core of the A. fumigatus cell wall is composed of a branched $\beta$-(1,3)-glucan (with less than $4 \%$ of $\beta$-(1,6)-branch points) [31,32] like as S. cerevisiae. Therefore, nagilactone E possibly shows an antifungal activity accompanying morphological changes of the hyphae. The MIC of nagilactone $\mathrm{E}$ was $50 \mu \mathrm{g} / \mathrm{mL}$ against $A$. fumigatus. Figure 5 indicates the hyphae treated with or without $200 \mu \mathrm{g} / \mathrm{mL}$ nagilactone E. In the treatment with the nagilactone $\mathrm{E}$, the hyphae themselves and the tips of the hyphae were significantly swollen as compared with the hyphae treated without the drug probably indicating the fragility of the cell wall.

\section{Discussion}

Nagilactone E shows antifungal activities against nonpathogenic S. cerevisiae and human pathogenic C. albicans and P. ovale [13]. However, the detailed antifungal mechanisms of nagilactone $\mathrm{E}$ have not yet been elucidated. To investigate the mechanisms, S. cerevisiae was used as a test organism in this study. Cell viability in ME medium was significantly and gradually reduced over the time course of drug exposure (Fig. 2). Additionally, a decrease in cell turbidity was observed in exponentially growing cells of a nagilactone E-hypersensitive strain (data not shown), which lacks the 13 genes of major 
multidrug pumps [33], indicating nagilactone E-induced cell lysis. However, in S-buffer, lacking energy sources, cell viability was maintained in cells treated with nagilactone E until 72-h drug exposure (Fig. 3c). These results indicate that nagilactone E only acted on yeast cells during proliferation. These phenomena were frequently observed in the case of cell wall-affecting antifungal drugs including mainly echinocandins [22, 25].

AmB induces $\mathrm{K}^{+}$leakage from fungal cells via $\mathrm{K}^{+}$-specific pore formation because of direct interaction between $\mathrm{AmB}$ and ergosterol [34]. The conventionally used nonionic surfactant Triton X-100 induces leakage of $260 \mathrm{~nm}$-absorbing materials including mainly nucleotides from cells due to non-specific disruption or solubilization of the plasma membrane phospholipids [22]. In addition, such membrane-affecting drugs often induce rapid lethality after drug exposure $[35,36]$. Nagilactone $E$ did not induce the leakage of $\mathrm{K}^{+}$ions and 260-nm-absorbing materials (Fig. 3) and induced slower lethality than that of typical agents causing membrane injury, indicating that the primary action of nagilactone $\mathrm{E}$ was not membrane disruption.

Phenomena such as the burst of cell walls and leakage of cytoplasmic constituents were observed when the yeast cells treated with nagilactone $\mathrm{E}$ were washed with a hypoosmotic solvent such as deionized water (Fig. 4b), indicating the fragility of cell walls induced by this compound. Hyperosmotic conditions such as $0.8 \mathrm{M}$ sorbitol 
weakened the antifungal effect of nagilactone E (Table 1). Therefore, nagilactone E probably affects a metabolic pathway associated with the cell wall. Mammalian cells do not contain the structure of fungal cell walls. Thus, the cell walls are considered a highly selective target of antifungal drugs [6, 7]. In fact, echinocandins, including MCFG, showing fewer adverse effects in humans were developed as specific inhibitors of fungal glucan synthase in human pathogenic C. albicans and Aspergillus spp. [30].

A primary constituent of the fungal cell wall, $(1,3)-\beta$-glucan, which consists long linear chains of $(1,3)-\beta$-linked glucose, is synthesized from UDP-glucose via the addition of monomeric glucose by the membrane embedded protein complex $(1,3)$ - $\beta$-glucan synthase [31]. The uniform thickness of cell walls observed in non-treated cells disappeared in nagilactone E-treated cells (Fig. 4), indicating the possibility of an effect of nagilactone $\mathrm{E}$ on glucan biosynthesis. We also confirmed nagilactone E-induced morphological changes against A. fumigatus (Fig. 5) supporting the effect of nagilactone E on the fungal cell wall, especially $(1,3)-\beta$-glucan. The amount of newly synthesized (1, 3)- $\beta$-glucan in membrane fractions significantly and dose-dependently decreased in nagilactone E-treated cells (Fig. 4c). The inhibition of glucan production would probably depend on the inhibition of $(1,3)$ - $\beta$-glucan synthase by nagilactone $E$, thereby inducing morphological alterations of the cell wall of $S$. cerevisiae. Therefore, the antifungal 
activity of nagilactone $\mathrm{E}$ could be partly explained by the inhibition of glucan production. However, the inhibition of glucan biosynthesis caused by nagilactone $\mathrm{E}$ was weaker than the inhibition caused by MCFG (Fig. 4c). This might be explained by the time required for nagilactone E to induce lethality in S. cerevisiae (Fig. 2).

Cell wall glucan exists not only in $S$. cerevisiae but also in C. albicans and Aspergillus spp. [7], which are opportunistic fungal pathogens that cause candidiasis and aspergillosis, respectively, in immunocompromised patients. As glucan is unique to the fungi, it is one of the most attractive targets of antifungals with fewer adverse effects. The antifungal activity of nagilactone E might be relatively weaker than that of antibiotics currently on the market. However, nagilactone $\mathrm{E}$ in combination with other antifungals, e.g., anethole [13], would probably show a synergistic antifungal effect, indicating that nagilactone E may contribute to the development of drugs against mycosis.

Other antifungal norditerpene dilactones, momilactones $\mathrm{A}$ and $\mathrm{B}$, are allelochemicals produced by the roots of rice in response to infection by a blast fungus Pyricularia oryzae [37, 38]. Although, the induction of nagilactone's production has not been reported by phytopathogenic fungal infections, nagilactones $\mathrm{E}$ and $\mathrm{F}$ were mainly contained in the root bark of $P$. nagi [39]. Therefore, nagilactone E possibly involves plant defense response against invasion of fungal pathogens into at least the roots in addition 
to the case of momilactones.

\section{Acknowledgement}

This work was partly funded by Japan Society for the Promotion of Science, Grants-inAid for Scientific Research (C) 25460128 and 16K08299.

\section{Conflict of interest}

The authors have no conflict of interest to declare.

\section{References}

[1] M.H. Miceli, J.A. Díaz, S.A. Lee, Emerging opportunistic yeast infections. Lancet Infect. Dis. 11 (2011) 142-151.

[2] A. Mark, M. D. Miller, Reversible hepatotoxicity related to amphotericin B. Can. Med. Assoc. J. 131 (1984) 1245-1247.

[3] M. Borgers, H. Degreef, G. Cauwenbergh, Fungal infections of the skin: Infection process and antimycotic therapy. Curr. Drug Targets 6 (2005) 849-862.

[4] M.M. Canuto, F.G. Roder, Antifungal drug resistance to azoles and polyenes. Lancet Infect. Dis. 2 (2002) 550-563. 
[5] P. Mazur, N. Morin, W. Baginsky, M. El-Sherbeini, J.A. Clemas, J.B. Nielsen, F. Foor, Differential expression and function of two homologous subunits of yeast $1,3-\beta$ D-glucan synthase. Mol. Cell. Biol. 15 (1995) 5671-5681.

[6] S.M. Bowman, S.J. Free, The structure and synthesis of the fungal cell wall. BioEssays 28 (2006) 799-808.

[7] C.C. Chiou, N. Mavrogiorgos, E. Tillem, R. Hector, T.J. Walsh, Synergy, pharmacodynamics, and time-sequenced ultrastructural changes of the interaction between Nikkomycin $\mathrm{Z}$ and the echinocandin FK463 against Aspergillus fumigatus. Antimicrob. Agents and Chemother. 45 (2001) 3310-3321.

[8] I. Kubo, M. Sutisna, K. S. Tan, Effects of nagilactones on the growth of lettuce seedlings. Phytochemistry 30 (1991) 455-456.

[9] Y. Ohmae, K. Shibata, T. Yamakura, Seasonal change in nagilactone contents in leaves in Podocarpus nagi forest. J. Chem. Ecol. 22 (1996) 477-489.

[10] I. Kubo, T. Matsumoto, J.A. Klocke, Multichemical resistance of the conifer Podocarpus gracilior (Podocarpaceae) to insect attack. J. Chem. Ecol. 10 (1984) 547-559.

[11] G.B. Russell, P.G. Fenemore, P. Singh, Insect-control chemicals from plants. Nagilactone C, A toxic substance from the leaves of Podocarpus nivalis and $P$. 
hallii. Aust. J. Biol. Sci. 25 (1972) 1025-1030.

[12] K. Shresthaa, A.H. Banskotab, S. Kodatab, S.P. Shrivastavac, G. Strobeld, M.B. Gewaria, An antiprolifelative norditerpene dilactone, nagilactone C, from Podocarpus nerifolius. Phytomedicine 8 (2001) 489-491.

[13] I. Kubo, H. Muroi, M. Himejima, Combination effects of antifungal nagilactones against Candida albicans and two other fungi with phenylpropanoids. J. Nat. Prod. 56 (1993) 220-226.

[14] K. Sato, Y. Inaba, H.S. Park, T. Akiyama, T. Koyama, H. Fukaya, Y. Aoyagi, K. Takeya, Cytotoxic bisnor- and norditerpene dilactones having 7 $\alpha, 8 \alpha$-epoxy-9,11enolide Substructure from Podocarpus macrophyllus D. DON. Chem. Pharm. Bull. 57 (2009) 668-679.

[15] K. Fujita, T. Ishikura, Y. Jono, Y. Yamaguchi, A. Ogita, I. Kubo, T. Tanaka, Anethole potentiates dodecanol's fungicidal activity by reducing $P D R 5$ expression in budding yeast. Biochim. Biophys. Acta 1861 (2017) 477-484.

[16] W.T. Langeveld, E.J. Veldhuizen, S.A. Burt, Synergy between essential oil components and antibiotics: a review. Crit. Rev. Microbiol. 40 (2014) 76-94.

[17] L. Owen, K. Laird, Synchronous application of antibiotics and essential oils: dual mechanisms of action as a potential solution to antibiotic resistance. Crit. Rev. 
Microbiol. 10 (2018) 1-22.

[18] T. Tanaka, K. Nakayama, K. Machida, M. Taniguchi, Long-chain alkyl ester of AMP acts as an antagonist of glucose-induced signal transduction that mediates activation of plasma membrane protein pump in Saccharomyces cerevisiae. Microbiology 146 (2000) 377-384.

[19] A. Ogita, Y. Nagao, K. Fujita, T. Tanaka, Amplification of vacuole-targeting fungicidal activity of antibacterial antibiotic polymyxin B by allicin, an allyl sulfur compound from garlic. J. Antibiot. 60 (2007) 511-518.

[20] C. Ikegawa, A. Ogita, T. Doi, F. Kumazawa, K. Fujita, T. Tanaka, Involvement of irreversible vacuolar membrane fragmentation in the lethality of food emulsifier diglycerol monolaurate against budding yeast. J. Agric. Food Chem. 65 (2017) $5650-5656$.

[21] K.A. Hammer, C.F. Carson, T.V. Riley, Antifungal effects of Melaleuca alternifolia (tea tree) oil and its components on Candida albicans, Candida glabrata and Saccharomyces cerevisiae. J. Antimicrob. Chemother. 53 (2004) 1081-1085.

[22] M. Yutani, Y. Hashimoto, A. Ogita, I. Kubo, T. Tanaka, K. Fujita, Morphological changes of the filamentous fungus Mucor mucedo and inhibition of chitin synthase activity induced by anethole. Phytother. Res. 25 (2011) 1707-1713. 
[23] D.J. Frost, K.D. Brandt, D. Cugier, R. Goldman, A whole-cell Candida albicans assay for the detection of inhibitors towards fungal cell wall synthesis and assembly. J. Antibiot. 48 (1995) 306-310.

[24] E. Shedletzky, C. Unger, D.P. Delmer, A microtiter-based fluorescence assay for (1, 3)- $\beta$-glucan synthases. Anal. Biochem. 249 (1997) 88-93.

[25] N. Mizuhara, Y. Usuki, M. Ogita, K. Fujita K, M. Kuroda, M. Doe, H. Lio, T. Tanaka, Identification of phoslactomycin E as a metabolite inducing hyphal morphological abnormalities in Aspergillus fumigatus IFO 5840. J. Antibiot. 60 (2007) 762-765.

[26] A. Ogita, K. Fujita, M. Taniguchi, T. Tanaka, Enhancement of the fungicidal activity of amphotericin B by allicin, an allyl-sulfur compound from garlic, against the yeast Saccharomyces cerevisiae as a model system. Planta Med. 72 (2006) 12471250.

[27] C.K. Kang, K. Yamada, Y. Usuki, A. Ogita, K. Fujita, T. Tanaka, Visualization analysis of the vacuole-targeting fungicidal activity of amphotericin B against the parent strain and an ergosterol-less mutant of Saccharomyces cerevisiae. Microbiology 159 (2013) 939-947.

[28] F.M. Klis, P. Mol, K. Hellingwerf, S. Brul, Dynamics of cell wall structure in Saccharomyces cerevisiae. FEMS Microbiol. Rev. 26 (2002) 239-256. 
[29] J.C. Kapteyn, H. Van Den Ende, F.M. Klis, The contribution of cell wall proteins to the organization of the cell wall. Biochim. Biophys. Acta, 1426 (1999) 373-383.

[30] D.W. Denning, Echinocandin antifungal drugs. Lancet 362 (2003) 1142-1151.

[31] A. Beauvais, J.M. Bruneau, P.C. Mol, M.J. Buitrago, R. Legrand, J.P. Latgé, Glucan synthase complex of Aspergillus fumigatus. J. Bacteriol. 183 (2001) 2273-2279.

[32] A. Beauvais, T. Fontaine, V. Aimanianda, J.P. Latgé, Aspergillus cell wall and biofilm. Mycopathologia 178 (2014) 371-377.

[33] T. Chinen, Y. Ota, Y. Nagumo, H. Masumoto, T. Usui, Construction of multidrugsensitive yeast with high sporulation efficiency. Biosci. Biotechnol. Biochem. 75 (2011) 1588-1593.

[34] M. Yoshioka, K. Yamada, Y. Yamaguchi, A. Ogita, K. Fujita, T. Tanaka, The fungicidal activity of amphotericin B requires autophagy-dependent targeting to the vacuole under a nutrient-starved condition in Saccharomyces cerevisiae. Microbiology 162 (2016) 848-854.

[35] T. Kondo, Y. Takaochi, Y. Yamaguchi, A. Ogita, K. Fujita, T. Tanaka, Vacuole disruption as the primary fungicidal mechanisms of action of polygodial, a sesquiterpene dialdehyde. Planta Med. Internat. Open 3 (2016) e72-e76.

[36] M. Iida, K. Yamada, Y. Nango, Y. Yamaguchi, A. Ogita, K. Fujita, T. Tanaka, 
Vacuolar $\mathrm{H}^{+}$-ATPase subunit Vmalp functions as the molecular ligand in the vacuole-targeting fungicidal activity of polymyxin B. Microbiology 163 (2017) $531-540$.

[37] T. Kato, C. Kabuto, N. Sasaki, M. Tsunagawa, H. Aizawa, K. Fujita, Y. Kato, Y. Kitahara, Momilactones, growth inhibitors from rice, Oryza sativa L. Tetrahedron Lett. 14 (1973) 3861-3864.

[38] T. Toyomasu, T. Kagahara, K. Okada, J. Koga, M. Hasegawa, W. Mitsuhashi, T. Sassa, H. Yamane, Diterpene phytoalexins are biosynthesized in and exuded from the roots of rice seedlings. Biosci. Biotechnol. Biochem. 72 (2008) 562-567.

[39] Y. Hayashi, J. Yokoi, Y. Watanabe, T. Sakan, Y. Masuda, R. Yamamoto, Structures of nagilactone $\mathrm{E}$ and $\mathrm{F}$, and biological activity of nagilactones as plant growth regulator. Chem. Lett. 1 (1972) 759-762. 


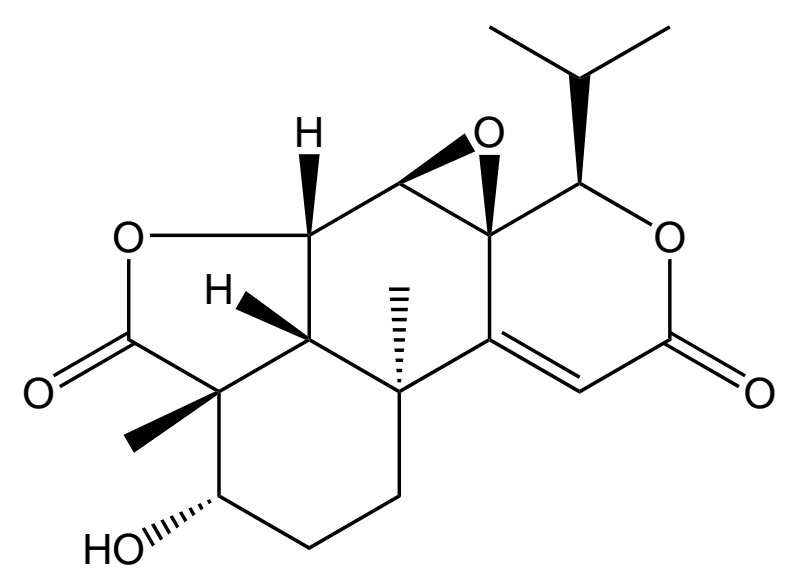

Fig. 1. The structure of nagilactone E. 


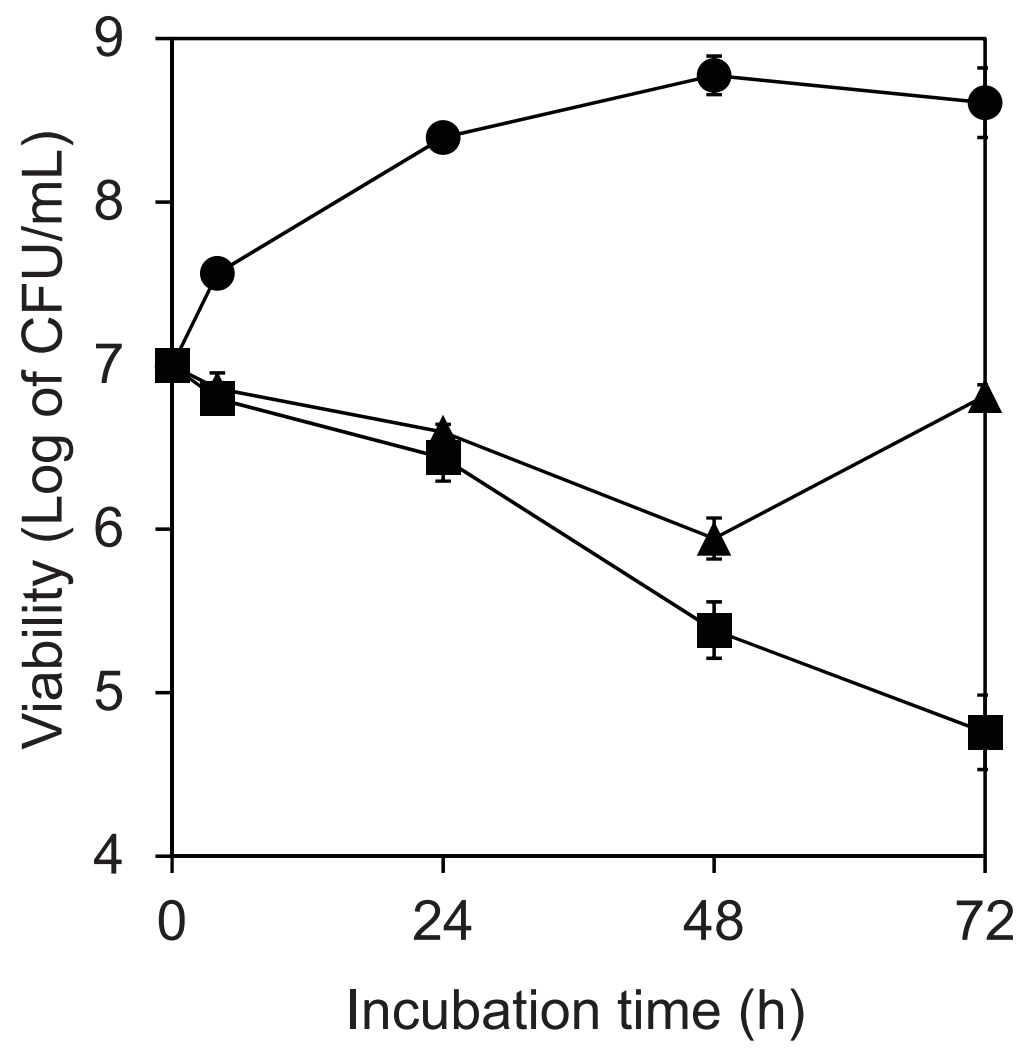

Fig. 2. Effects of nagilactone E on the cell viability of $S$. cerevisiae BY4741 cells. The cells $\left(1 \times 10^{7}\right.$ cells $\left./ \mathrm{mL}\right)$ of $S$. cerevisiae BY 4741 were incubated at $30^{\circ} \mathrm{C}$ in $2.5 \% \mathrm{ME}$ broth with 0 (circle), 100 (triangle), and 200 (square) $\mu \mathrm{g} / \mathrm{mL}$ nagilactone E. Data are means \pm standard deviations of triplicate experiments. 
(a)

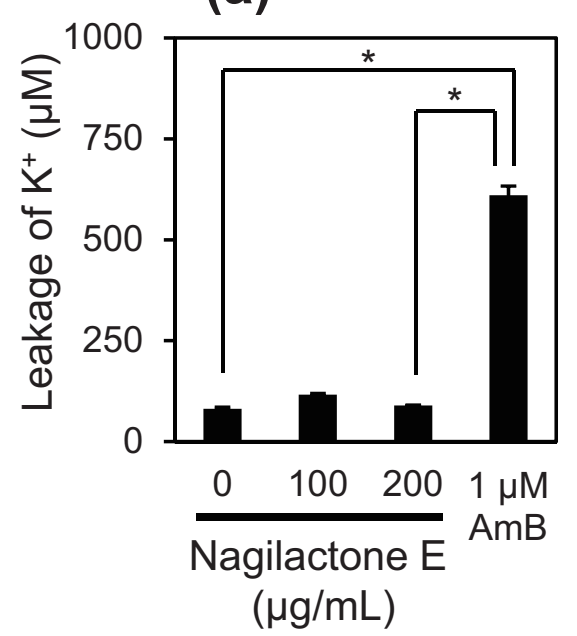

(b)

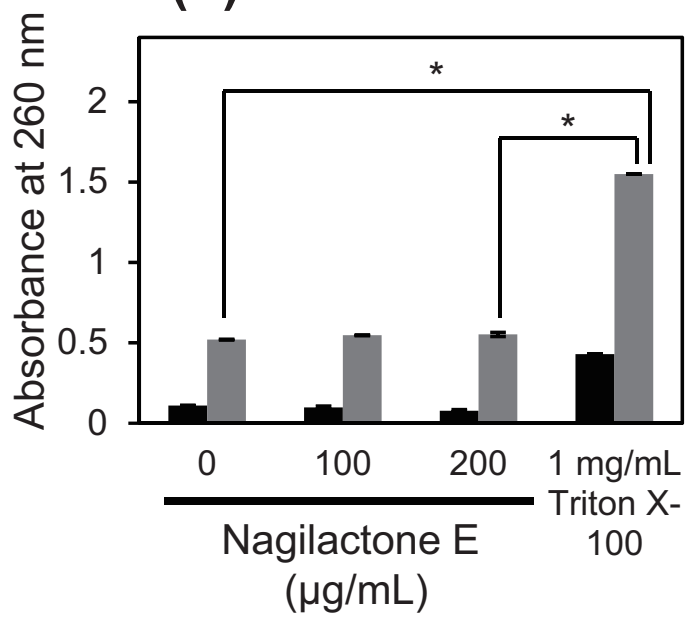

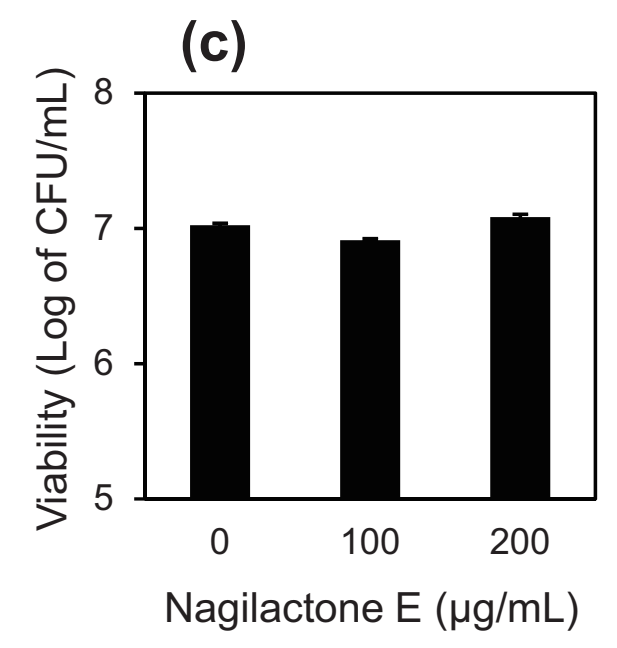

Fig. 3. Effects of nagilactone $\mathrm{E}$ on the leakage of $\mathrm{K}^{+}$ions (a) and 260 -nm-absorbing materials (b) from cells and on the cell viability (c) in S-buffer. The S. cerevisiae BY4741 cells were incubated at $30{ }^{\circ} \mathrm{C}$ in S-buffer with or without nagilactone $\mathrm{E}$ prior to the following assays. In (a), after incubation for $4 \mathrm{~h}$, the leakage of $\mathrm{K}^{+}$ions from cells was measured in the supernatant. Amphotericin B (AmB) was used as a positive control. In (b), after incubation for 4 (black) and 72 (gray) h, the leakage of 260-nm-absorbing 
materials from cells was estimated in the supernatant. Triton X-100 was used as a positive control. In (c), after incubation for $72 \mathrm{~h}$, the cell viability was estimated based on CFU. Data are means \pm standard deviations of triplicate experiments, and the asterisks indicate significant differences. 

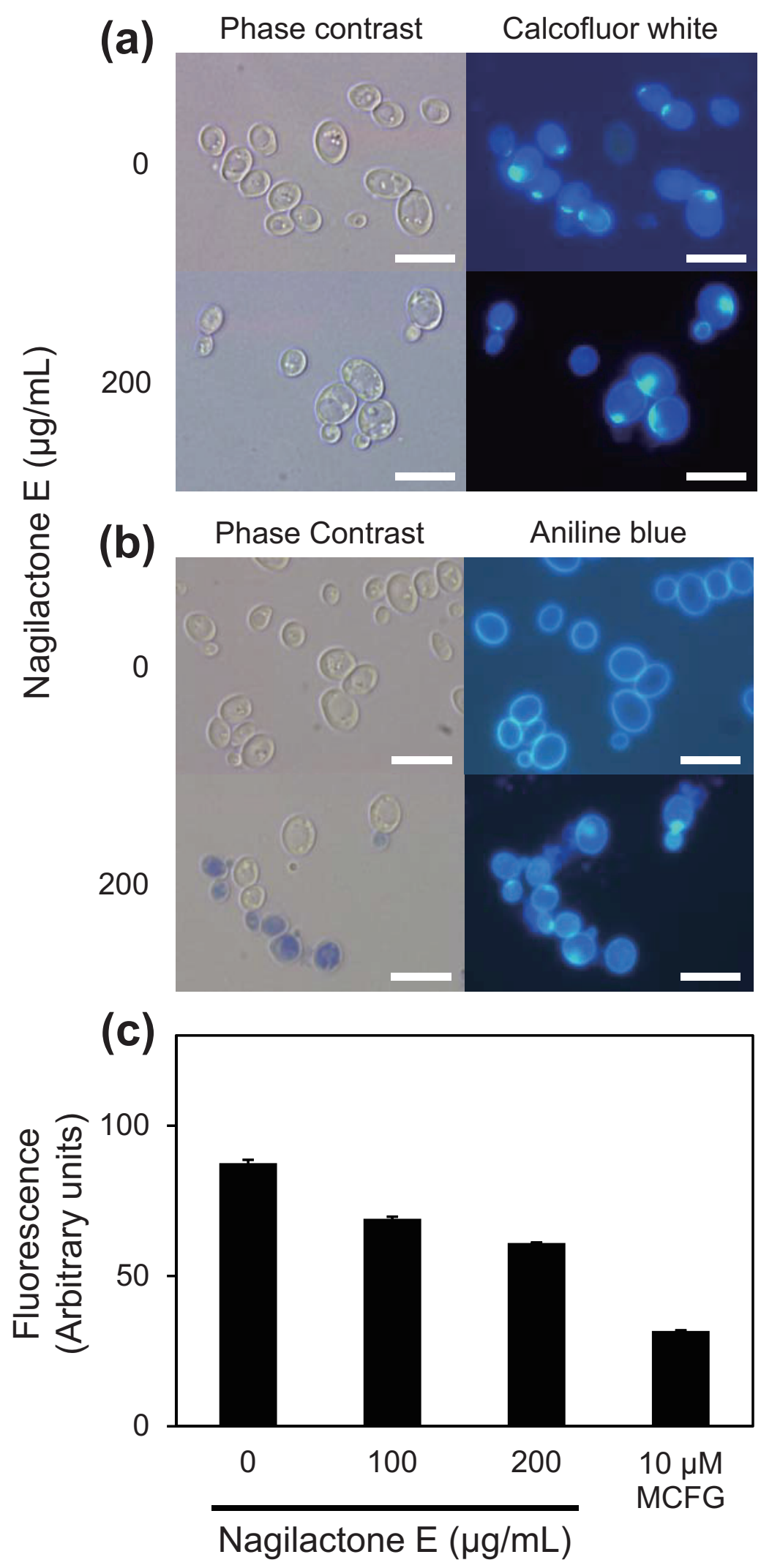
Fig. 4. Visualization of chitin and glucan in cell wall and effects of nagilactone E on increase in fluorescence derived from aniline blue-glucan complex in membrane fractions of yeast cells. In (a) and (b), the cells of S. cerevisiae BY4741 were incubated at $30{ }^{\circ} \mathrm{C}$ for $72 \mathrm{~h}$ in $2.5 \% \mathrm{ME}$ broth with 0 and $200 \mu \mathrm{g} / \mathrm{mL}$ nagilactone $\mathrm{E}$ and then stained with $1 \mathrm{mg} / \mathrm{mL}$ calcofluor white (a) and $5 \mathrm{mg} / \mathrm{mL}$ aniline blue (b) for chitin and glucan, respectively, at $25^{\circ} \mathrm{C}$ for $5 \mathrm{~min}$. The cells were observed under a phase-contrast (left) and a fluorescence (right) microscope with Ex: $330 \mathrm{~nm}$ and Em: $385 \mathrm{~nm}$. Bar $=10$ $\mu \mathrm{m}$. In (c), reaction mixtures containing isolated membrane fractions were incubated with nagilactone $\mathrm{E}$ and micafungin (MCFG; as a positive control) at $30^{\circ} \mathrm{C}$ for $30 \mathrm{~min}$. Fluorescence derived from aniline blue bound with $(1,3)-\beta$-glucan was measured at excitation/emission $=400 / 460 \mathrm{~nm}$. The fluorescence shows the amount of newly synthesized (1, 3)- $\beta$-glucan. Data are means \pm standard deviations of triplicate experiments, and the asterisks indicate significant differences. 


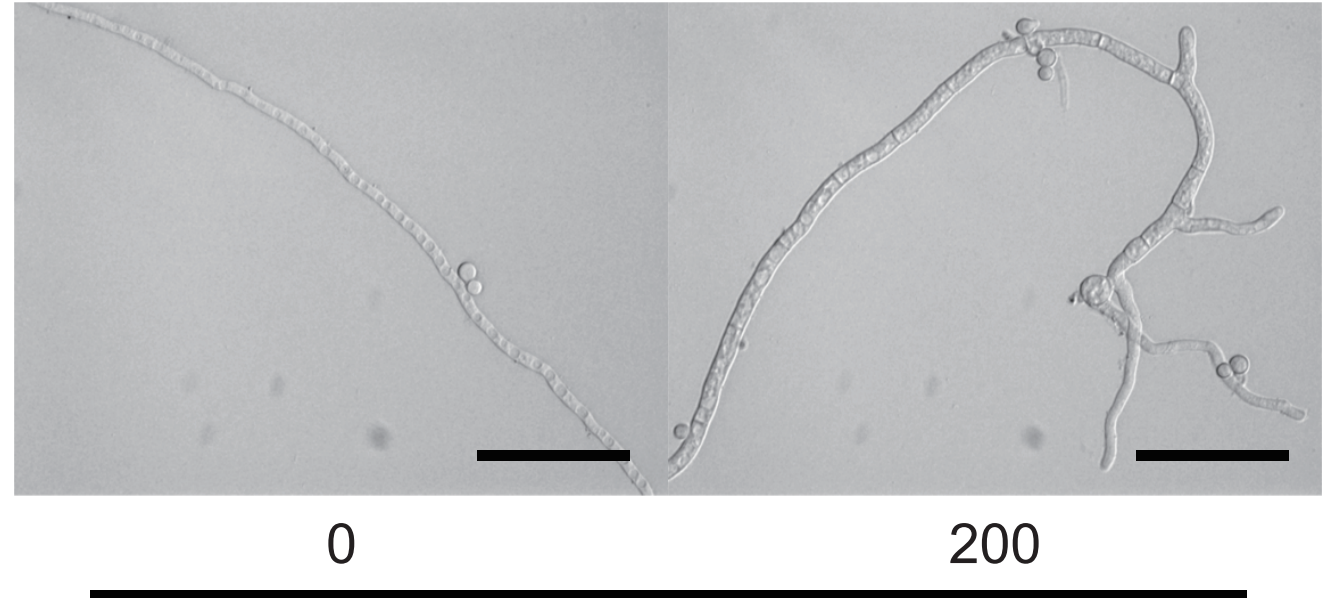

Nagilactone $E(\mu \mathrm{g} / \mathrm{mL})$

Fig. 5. Effect of morphology on the hyphae of A. fumigatus. The spores of A. fumigatus IFO5840 were germinated and then incubated at $30{ }^{\circ} \mathrm{C}$ for $24 \mathrm{~h}$ in $2.5 \% \mathrm{ME}$ broth with 0 and $200 \mu \mathrm{g} / \mathrm{mL}$ nagilactone E. The hyphae were washed and then incubated in deionized water at $25^{\circ} \mathrm{C}$ for $1 \mathrm{~h}$ in prior to taking microphotographs. Bar $=10 \mu \mathrm{m}$. 
Table 1

Effect of sorbitol on the MIC of nagilactone E against $S$. cerevisiae BY4741

\begin{tabular}{ccc}
\hline $0.8 \mathrm{M}$ & \multicolumn{2}{c}{$\mathrm{MIC}(\mu \mathrm{g} / \mathrm{mL})$} \\
\cline { 2 - 3 } Sorbitol & After 2 days & After 7 days \\
\hline No addition & 25 & 50 \\
Addition & 25 & 100 \\
\hline
\end{tabular}

